Creative Commons User License: CC BY-NC-ND

Abstracted by: EBSCOhost, Electronic Journals Service (EJS), Google Scholar, Journal Seek, Scientific Commons,

Food and Agricultural Organization (FAO), CABI and Scopus

http://eoi.citefactor.org/10.11226/v25i4
Journal of Agricultural Extension

Vol. 25 (4) October, 2021

ISSN(e): 24086851; ISSN(Print); 1119944X

http://journal.aesonnigeria.org

http://www.ajol.info/index.php/jae

Email: editorinchief@aesonnigeria.org

\title{
Determinants of Catfish Farmers' Use of Sustainable Environmental Management Practices in Enugu State, Nigeria
}

https://dx.doi.org/10.4314/jae.v25i4.15

\section{Chukwuone Nnaemeka Andegebe}

Department of Agricultural Economics and Resource and Environmental Policy Research Centre, University of Nigeria, Nsukka, Enugu State, Nigeria.

nnaemeka.chukwuone@unn.edu.ng, +2348051242411

\section{Onyia Chukwuemeka Chiebonam}

Corresponding author

Department of Agricultural Economics and Resource and Environmental Policy Research Centre, University of Nigeria, Nsukka, Enugu State, Nigeria.

chukwuemeka.onyia@unn.edu.ng, +2347030852594

\section{Aniokoh Chukwuebuka David}

Department of Agricultural Economics, University of Nigeria, Nsukka, Enugu State, Nigeria. chukwuebuka.aniokoh.197413@unn.edu.ng, +2348168934131

\section{Abstract}

The study assessed the use of sustainable environmental management practices (SEMP) by fish farmers in Enugu state, Nigeria. Seventy-five catfish farmers selected through multistage sampling procedure were used for the study. Data were obtained with the aid of a well-structured questionnaire. Analysis of data was done using descriptive statistics, probit regression model and factor analysis. Results showed that most of the catfish farmers did not apply SEMP as only $25.33 \%$ of them had a score of $50 \%$ and above regarding the application of SEMP. The number of years spent in school and being a male significantly increased the likelihood of using SEMP. In contrast, the likelihood of use of SEMP significantly reduced with an increase in the number of production cycles carried out by a fish farmer. The fish farmers' constraints were grouped as poor technical knowledge and feed issues, financial uncertainties, and water supply problems. Government should deliver training packages and provide information on SEMP to catfish farmers through different media, including extension agents, radio and television messages, handbills and billboards. Supporting the farmers with credit facilities through existing credit programmes would help reduce their challenges in applying SEMP.

Keywords: sustainable practices, environmental management, catfish farmers

\section{Introduction}

Aquaculture, especially fish farming, gained prominence over the years due to the decline in biomass and catch of wild fish as well as the need to meet protein requirements and achieve food security among the world's surging population (Food and Agricultural Organization (FAO) 2016; Pauly and Zeller 2017). Aquaculture 
Creative Commons User License: CC BY-NC-ND

Abstracted by: EBSCOhost, Electronic Journals Service (EJS), Google Scholar, Journal Seek, Scientific Commons,

Food and Agricultural Organization (FAO), CABI and Scopus

http://eoi.citefactor.org/10.11226/v25i4
Journal of Agricultural Extension

Vol. 25 (4) October, 2021

ISSN(e): 24086851; ISSN(Print); 1119944X

http://journal.aesonnigeria.org

http://www.ajol.info/index.php/jae

Email: editorinchief@aesonnigeria.org

accounts for more biomass than captured fisheries and is responsible for more protein than fish from wild catches; thus, the sector is considered the fastest-growing food technology globally (Golden et al., 2017; Edwards, Zhang, Belton, and Little, 2019). The sector contributes $47 \%$ of fish production globally, with a growth rate of $5.8 \%$ witnessed between 2001 and 2016 (FAO, 2016, 2018).

In Nigeria, output from aquaculture, mainly catfish farming (FAO, 2017), has increased over the years, growing from 21700 tonnes in 1999 to 316700 tonnes in 2015 (Federal Ministry of Agriculture and Rural Development (FMARD), 2017). However, despite increased production over the years, the average output of 1.5 tons/hectare/year from the sector is well below its potential of 15 tons/hectare/year (FMARD, 2017). The poor output per hectare could be due to fish farmers' inadequate production and weak environmental management practices in Nigeria. Boyd et al. (2020) echoed the need for technologies that enhance productivity while reducing the environmental footprint of aquaculture as increase in fish production has been linked to some negative environmental impacts (Obiero et al., 2019). Thus, one of the approaches for promoting good fish farming is promoting sustainable environmental management practices (Farm Africa: Kenya Market-Led Aquaculture Programme, 2016). Sustainability is seen as the ability of human activities to persist over time while maintaining a healthy environment (Boyd et al., 2020). Thus, sustainable management practices would help achieve more resilient and productive food systems and facilitate sustainable production, especially in aquaculture, which would help ensure food security and poverty reduction (Piñeiro et al. 2020).

Negative environmental impacts in fish production result mainly from waste production and improper waste management and disposal of untreated effluents to the surroundings, and escape of fishes which can result in changes in wild fish genotype and thus affect biodiversity (White, 2017; Dauda et al., 2019). Sustainable environmental management practices in fish production are facilitated through efficient pond management, including water quality management, adequate feed input and disease control and management practices, proper waste management (both solid and dissolved wastes) (Dauda et al., 2019).

Some previous studies have determined the factors that influence the adoption of improved technologies in aquaculture. Kumar et al. (2018) found that perception of technology as cost-effective and easy to manage, cheap in price, and high expected profits positively and significantly enhanced the likelihood of adoption. Obiero et al. (2019) found that having secondary education and above, fish farm size, diversified on-farm activities, attendance to extension training, ease of handling technologies, production levels and satisfaction with extension service are positively and significantly associated with aquaculture technology adoption. However, notwithstanding some studies on the adoption of production technologies, studies on sustainable environmental management practices in aquaculture that could guide evidence-based policy in environmental management are lacking. Hence the questions are: what is the level of involvement of fish farmers in carrying out some sustainable environmental management practices? What factors influence the use of sustainable environmental management practices? What are the constraints to the implementation of sustainable environmental management practice? This study, therefore, assessed the use of sustainable environmental management practices 
Creative Commons User License: CC BY-NC-ND

Abstracted by: EBSCOhost, Electronic Journals Service (EJS), Google Scholar, Journal Seek, Scientific Commons,

Food and Agricultural Organization (FAO), CABI and Scopus

http://eoi.citefactor.org/10.11226/v25i4
Journal of Agricultural Extension

Vol. 25 (4) October, 2021

ISSN(e): 24086851; ISSN(Print); 1119944X

http://journal.aesonnigeria.org

http://www.ajol.info/index.php/jae

Email: editorinchief@aesonnigeria.org

and constraints militating against the application of sustainable environmental management practices by catfish farmers in Enugu State, Nigeria.

\section{Methodology}

The study area was Enugu state, southeast geo-political zone of Nigeria. It is composed of 17 local government areas and 291 political wards. The state has a total landmass of about $8,022.96 \mathrm{~km}^{2}$ and a population of about 4,185,509 (National Population Census (NPC), 2006). It lies between latitudes $5^{0} 56^{\prime} \mathrm{N}$ and $7^{0} 06^{\prime} \mathrm{N}$ and longitudes $6^{\circ} 53^{\prime} \mathrm{E}$ and $7^{0} 55^{\prime} \mathrm{E}$.

Multistage sampling procedure was used in selecting the respondents. In the first stage, the predominant Local Government Areas where fish farming is practiced were mapped out with the help of officers in the Fisheries Department of Enugu State Ministry of Agriculture. In the second stage, from the mapped local government areas (LGA) in Enugu State, five LGAs were randomly selected for the study, namely; Udi, Enugu East, Enugu South, Nkanu West and Nsukka. Before the third stage sampling, a list of fish farmers in the sampled LGAs was compiled with the help of officers in the Fisheries Department of Enugu State Ministry of Agriculture and the staff of the agricultural department of the LGAs. The list was made up of 40, 40, 30, 20 and 20 fish farmers from Udi, Enugu East, Enugu South, Nkanu West, and Nsukka respectively. In the second stage, $50 \%$ of the compiled fish farmers were sampled using proportionate random sampling, giving a sample size of 75 fish farmers for the study.

Primary data were obtained through the administration of well-structured and validated questionnaires. The questionnaire was validated by five experts drawn from the faculty of agriculture and biological sciences, University of Nigeria Nsukka. The questionnaire was used to obtain information such as socioeconomic characteristics of fish farmers, various environmental management practices by the fish farmers, and constraints to sustainable environmental management. Eight different environmental management practices were provided to the fish farmers, from which they indicated the ones practiced. The practices include measuring dissolved oxygen in pond, having a security device in a pond, treat wastewater before disposing of, experience fish escape, proper handling of predators, clean pond after each production cycle, proper effluent disposal (not released indiscriminately to the surroundings) and having a documented waste management strategy to avoid waste build-up. The fish farmers were asked to indicate yes or no for each of the practices. The application of the itemized sustainable environmental management practices in their farms was confirmed during a visit to the farms for data collection. However, this was not applicable for some practices, namely, proper handling of predators, which the farmers indicated whether they killed predators or not, the experience of fish escape and cleaning of ponds after each production cycle, and proper effluent disposal.

Mean, and percentage, were applied to describe the socioeconomic attributes of the fish farmers and the sustainable environmental management practices they employed. A probit model was applied to estimate determinants of use of sustainable environmental management practices. First, the respondents were scored following their responses regarding the eight practices. Correct practice was assigned a score of 1 . These scores were added up to obtain a percentage score. Those that scored 
Creative Commons User License: CC BY-NC-ND

Abstracted by: EBSCOhost, Electronic Journals Service (EJS),

Google Scholar, Journal Seek, Scientific Commons,

Food and Agricultural Organization (FAO), CABI and Scopus

http://eoi.citefactor.org/10.11226/v25i4
Journal of Agricultural Extension

Vol. 25 (4) October, 2021

ISSN(e): 24086851; ISSN(Print); 1119944X

http://journal.aesonnigeria.org

http://www.ajol.info/index.php/jae

Email: editorinchief@aesonnigeria.org

$50 \%$ and above were considered as practicing sustainable environmental management in fish production, while those that scored less than $50 \%$ were considered as not practicing sustainable environmental management. Thus, in the probit model, the practice of sustainable environmental management in fish production, $y_{i}$, is the dependent variable (it takes a value of 1 if the fish farmer practices (having a score of $50 \%$ and above), and 0 if otherwise). In this estimation, the dependent variable is a latent variable $y^{*}$ determined by a set of explanatory variables, which form part of the vector $x^{\prime}$. The model is generally given as:

$$
y_{i}^{*}=x_{i}^{z} \beta+u_{i}
$$

$y_{i}=1$ if $y_{i}^{*}>0 ; y_{i}=0$ if $y_{i}^{*} \leq 0$

where the subscript $i$ means fish farmers; the vector $\beta$ is the model parameters; and $u$ is the error term, which is normally distributed with a 0 mean and variance that equals 1. Thus, the model for estimating the determinants of the practice of sustainable environmental management (SEM) is specified as follows:

$S E M_{\mathrm{i}}=\beta_{1}+\beta_{2}$ Hou_size $_{\mathrm{i}}+\beta_{3}$ Gender $_{\mathrm{i}}+\beta_{4}$ number_years_school $_{\mathrm{i}}+\beta_{5}$ credit_access $_{\mathrm{i}}+$ $\beta_{6}$ num_years_expe_fish_farming ${ }_{i}+\beta_{7}$ quantity_finger_stocked_last_one_year ${ }_{i}+$ $\beta_{8}$ num_cycles_produ_last_one_year $_{i}$

Maximum-likelihood estimation of the probit models was carried out and the marginal effects were equally calculated. The variables included in the model were those with calculated variance inflation factor (VIF) of less than ten (10), suggesting that multicollinearity was not present. According to Greene (2018), a variable is assumed to be collinear if VIF exceeds 10 . The description of how the variables used in the model were measured is as shown in Table 1.

Furthermore, exploratory factor analysis was used to group the constraints to sustainable environmental management practices identified by the fish farmers. The factor analysis was implemented using the principal factor model with varimax rotation. After varimax rotation, variables whose loadings are from 0.45 and above, suggesting a $20 \%$ overlapping variance considered fair were used to name the factors.

Table 1: Variables used in model estimated

Variable Description

Number of years spent schooling by the Number of years spent in school household head

Household size

Gender of household head - Males

Access to credit facilities

Number of years of experience in fish Number of years of experience farming
Household size of members of the household

Dummy takes the value of 1 if male and 0 otherwise

Dummy takes the value of 1 if fish farmer has access to credit facilities and 0 otherwise. 
Creative Commons User License: CC BY-NC-ND

Abstracted by: EBSCOhost, Electronic Journals Service (EJS), Google Scholar, Journal Seek, Scientific Commons,

Food and Agricultural Organization (FAO), CABI and Scopus

http://eoi.citefactor.org/10.11226/v25i4
Journal of Agricultural Extension

Vol. 25 (4) October, 2021

ISSN(e): 24086851; ISSN(Print); 1119944X

http://journal.aesonnigeria.org

http://www.ajol.info/index.php/jae

Email: editorinchief@aesonnigeria.org

Number of fingerlings stocked in the last Number of fingerlings stocked one year of operation

Number of cycles of production in the Number of cycles of production last year

\section{Results and Discussion}

\section{Descriptive Statistics of Explanatory Variables Used in the Model}

Table 2 shows the means and standard deviation of the explanatory variables used in the model. The result shows that the fish farmers' average number of years spent in school was 14, suggesting that the majority had some secondary and above education. The average household size was six persons, and the average number of years of experience in fish farming was five years. Also, the average number of production cycles and fingerlings stocked in the last year preceding the interview were 3 and 6,183 , respectively. In addition, $77 \%$ of the fish farmers were males.

Table 2: Description, variable means and standard deviation

\begin{tabular}{lllll}
\hline Variables & Means & $\begin{array}{l}\text { Standard } \\
\text { Deviation }\end{array}$ & Maximum & Minimum \\
\hline $\begin{array}{l}\text { Number of years spent schooling by the } \\
\text { household head }\end{array}$ & 13.89 & 3.74 & 6 & 24 \\
$\begin{array}{l}\text { Household size } \\
\text { Gender of household head - Males }\end{array}$ & 5.61 & 3.44 & 0 & 22 \\
$\begin{array}{l}\text { Access to credit facilities } \\
\text { Number of years of experience in fish farming }\end{array}$ & 0.77 & 0.42 & 0 & 1 \\
$\begin{array}{l}\text { Number of fingerlings stocked in the last one } \\
\text { year of operation }\end{array}$ & 6182.80 & 17456.28 & 60 & 100,000 \\
$\begin{array}{l}\text { Number of cycles of production in the last } \\
\text { year }\end{array}$ & 2.8 & 1.76 & 1 & 10 \\
\hline
\end{tabular}

Source: Field survey data, 2021.

\section{Sustainable Environmental Management Practices by farmers}

The result regarding the fish farmers' sustainable environmental management practices is shown in Table 3 . The overall result shows that only $25.33 \%$ (based on the score of $50 \%$ and above) of the fish farmers employed sustainable environmental management practices. Although the majority $(76.00 \%, 73.33 \%$, and $60.00 \%)$ of the fish farmers had security devices in ponds, clean ponds after each production cycle, and did not experience fish escape respectively, a very low proportion $(13.33 \%$ and $1.33 \%$ ) of the fish farmers did not have a strategy for reducing waste build-up and do not treat wastewater before disposal respectively. This finding suggests that the majority of fish farmers in the area did not employ sustainable environmental management practices in aquaculture. This finding equally suggests that fish 
Creative Commons User License: CC BY-NC-ND

Abstracted by: EBSCOhost, Electronic Journals Service (EJS),

Google Scholar, Journal Seek, Scientific Commons,

Food and Agricultural Organization (FAO), CABI and Scopus

http://eoi.citefactor.org/10.11226/v25i4
Journal of Agricultural Extension

Vol. 25 (4) October, 2021

ISSN(e): 24086851; ISSN(Print); 1119944X

http://journal.aesonnigeria.org

http://www.ajol.info/index.php/jae

Email: editorinchief@aesonnigeria.org

production in the area is polluting the environment and that output is sub-optimal with reduced income for the fish farmers. This result could be one of the reasons why the 1.5 tons/hectare/year average output from aquaculture in Nigeria is well below its potential of 15 tons/hectare/year (FMARD, 2017).

Table 3: Sustainable environmental management practices used by the fish farmers

\section{Sustainable Environmental Management Practice}

$\%$ of fish farmers using the practice

Measure dissolved oxygen in ponds

30.67

Have a security device in a pond

76.00

Treat wastewater before disposing

No fish escape from ponds

60.00

Handle predators properly- not killing predators but scare them

38.67 aware

Clean pond after each production cycle

Has strategy for reducing waste build-up in ponds

Proper effluent disposal (not released indiscriminately to the surrounds)

Percentage with sustainable environmental management practice (overall score of $50 \%$ and above)

Source: Field survey data, 2021

\section{Determinants of Sustainable Environmental Management Practices by Fish Farmers}

The parameter estimates and marginal effects of the determinants of sustainable environmental management practices employed by the fish farmers are presented in Table 4. The result shows that the likelihood of applying sustainable environmental management practices by fish farmers significantly (at a 5\% probability level) increases with being a male farmer (1.276) and the number of years spent in school (0.150). Specifically, the result shows that the likelihood of using sustainable environmental management practices increases by $31.6 \%$ and $3.7 \%$ with being a male and spending more years in school. The result suggests that fish farmers who are male and have spent more years in school are likely to employ sustainable environmental management practices in fish farming. This high marginal effect of education underscores the need to provide fish farmers, especially male ones, with good training and knowledge of sustainable environmental management practices in fish farming. The finding is in line with Obiero et al. (2019) that secondary education and above and extension training are positively and significantly associated with aquaculture technology adoption.

On the other hand, the result also shows that the likelihood of use of sustainable environmental management practice significantly (at $5 \%$ probability level) reduces by 
Creative Commons User License: CC BY-NC-ND

Abstracted by: EBSCOhost, Electronic Journals Service (EJS), Google Scholar, Journal Seek, Scientific Commons,

Food and Agricultural Organization (FAO), CABI and Scopus

http://eoi.citefactor.org/10.11226/v25i4
Journal of Agricultural Extension

Vol. 25 (4) October, 2021

ISSN(e): 24086851; ISSN(Print); 1119944X

http://journal.aesonnigeria.org

http://www.ajol.info/index.php/jae

Email: editorinchief@aesonnigeria.org

$10 \%$ with an increase in the number of production cycles carried out by a fish farmer. This finding suggests that fish farmers who carry out many production cycles are less likely to employ sustainable environmental management practices. This finding equally shows that increased production level does not support the use of sustainable environmental management practices, contrary to Obiero et al. (2019), who reported that production level significantly enhances the adoption of aquaculture technology. This result is expected as fish farmers may neglect sustainable environmental practices with increased production levels to meet the commitments that many production cycles will involve, especially when they do not have the required knowledge.

Table 4: Determinants of sustainable management practices employed by the fish farmers

\begin{tabular}{lll}
\hline Explanatory Variables & Coefficients & Marginal Effects \\
\hline Gender & $1.276^{*}(0.497)$ & $0.316^{*}(0.106)$ \\
Number of years in school & $0.150^{*}(0.075)$ & $0.037^{*}(0.017)$ \\
Access to credit & $-0.175(0.538)$ & $-0.043(0.133)$ \\
Number of years of experience in fish & $-0.045(0.049)$ & $-0.011(0.012)$ \\
farming & & \\
Household size & $-0.042(0.058)$ & $-0.010(0.014)$ \\
Number of fingerlings stocked & $-3.63 \times 10^{-6}(0.00003)$ & $-8.97 \times 10^{-7}\left(8.31 \times 10^{-}\right.$ \\
& & $6)$ \\
Number of production cycles & $-0.406^{*}(0.204)$ & $-0.100^{*}(0.046)$ \\
Constant & $-0.286(1.209)$ & \\
Number of observations & 75 & \\
LR chi (7) & 18.33 & \\
Prob> chi2 & 0.010 & \\
Log likelihood & -33.283 &
\end{tabular}

Source: Computed from field survey data, 2021. Note: ${ }^{*} \mathrm{P} \leq 0.05$. Variables in parenthesis are standard errors.

Constraints to Sustainable Environmental Management Practices by Fish Farmers

Furthermore, the result of factor loadings regarding the constraints to sustainable environmental management practices, as indicated by fish farmers, is presented in Table 5. Three factors were extracted as those that constrain the fish farmers from using sustainable environmental management practices. Factor 1 was named poor technical knowledge and feed issues, while factors 2 and 3 were named financial uncertainties and water supply problems, respectively. The findings suggest the need to provide fish farmers with adequate knowledge, financial incentives and improved water supply to facilitate sustainable environmental management practices. Having adequate knowledge was also found to be one of the significant 
Creative Commons User License: CC BY-NC-ND

Abstracted by: EBSCOhost, Electronic Journals Service (EJS), Google Scholar, Journal Seek, Scientific Commons,

Food and Agricultural Organization (FAO), CABI and Scopus

http://eoi.citefactor.org/10.11226/v25i4
Journal of Agricultural Extension

Vol. 25 (4) October, 2021

ISSN(e): 24086851; ISSN(Print); 1119944X

http://journal.aesonnigeria.org

http://www.ajol.info/index.php/jae

Email: editorinchief@aesonnigeria.org

determinants of the application of sustainable environmental management practices in aquaculture.

Table 5: Constraints to the use of sustainable environmental management practices

\begin{tabular}{llll}
\hline Constraints & $\begin{array}{l}\text { Factor 1 (Poor } \\
\text { Technical } \\
\text { Knowledge and } \\
\text { Feed Issues }\end{array}$ & $\begin{array}{l}\text { Factor 2 } \\
\text { (Financial } \\
\text { uncertainties) }\end{array}$ & $\begin{array}{l}\text { Factor 3 (Water } \\
\text { supply problems) }\end{array}$ \\
& & & \\
\hline
\end{tabular}

High illiteracy level among $\quad 0.814$

the catfish farmers

Inadequate monitoring $\quad 0.778$

and evaluation

Poor technical knowledge $\quad 0.655$

Inadequate feed supply $\quad 0.636$

Lack of quality feed $\quad 0.575$

Lack of capital $\quad .777$

Poor access to credit $\quad .739$

High cost of feeds $\quad .630$

Lack of adequate space $\quad .594$

for fish farming

Fear of uncertainties

Inadequate water supply $\quad .806$

Insufficient water in the $\quad .608$

dry season

Lack of adequate

information

\section{Source: Field survey, 2021}

\section{Conclusion and Recommendations}

Based on the findings, one can conclude that most fish farmers do not apply sustainable environmental management practices. Given the effect of poor sustainable environmental management practices on fish production, this could be one of the reasons for the low output per hectare recorded in fish farming in Nigeria. Enhancing the education and knowledge of male catfish farmers can stimulate the use of sustainable environmental management practices in aquaculture. On the other hand, deliberate targeting of female fish farmers with training and information 
Creative Commons User License: CC BY-NC-ND

Abstracted by: EBSCOhost, Electronic Journals Service (EJS),

Google Scholar, Journal Seek, Scientific Commons,

Food and Agricultural Organization (FAO), CABI and Scopus

http://eoi.citefactor.org/10.11226/v25i4
Journal of Agricultural Extension

Vol. 25 (4) October, 2021

ISSN(e): 24086851; ISSN(Print); 1119944X

http://journal.aesonnigeria.org

http://www.ajol.info/index.php/jae

Email: editorinchief@aesonnigeria.org

on sustainable environmental management practices is required to encourage them to adopt the practices. Also, targeting farmers with increased production levels, especially those involved in many cycles of fish production, who are likely to avoid sustainable environmental management practices are required to reduce the environmental footprint of aquaculture. In addition, enhancing access to credit for fish farmers will reduce their challenges in employing sustainable environmental management practices.

Acknowledgement: The authors gratefully acknowledge research funding from the Swedish

International Development Cooperation Agency (Sida) through the Environment for Development (EfD) Initiative at the University of Gothenburg, under the Sustainable Fisheries and Aquaculture Management Project.

\section{References}

Boyd, C. E., D’Abramo, L. R., Glencross, B. D., Huyben, D. C., Juarez, L. M., Lockwood, G. S., McNevin, A. A., Tacon, A. G. C., Teletchea, F., Tomasso Jr, J. R., Tucker, C. S., Valenti, W. C. (2020). Achieving sustainable aquaculture: Historical and current perspectives and future needs and challenges. Journal of the World Aquaculture Society, 51(3), 578-633. doi:10.1111/jwas.12714

Dauda, A. B., Ajadi, A., Tola-Fabunmi, A. S., \& Akinwole, A. O. (2019). Waste production in aquaculture: Sources, components and managements in different culture systems. Aquaculture and Fisheries, 4, 8188. doi:10.1016/j.aaf.2018.10.002

Edwards, P., Zhang, W., Belton, B., and Little, D. C. (2019). Misunderstandings, myths, and mantras in aquaculture: Its contribution to world food supplies has been systematically overreported. Marine Policy, 106, 103547.

Food and Agricultural Organization (FAO) (2016) The state of world fisheries and aquaculture 2016 - contributing to food security and nutrition for all. Food and Agriculture Organization of the United Nations, Rome, Italy.

Food and Agricultural Organization (FAO) (2017) Fisheries and aquaculture country profile of the federal republic of Nigeria. http://www.fao.org/fishery/facp/NGA/en.

Food and Agricultural Organization (FAO) (2018) The state of world fisheries and aquaculture 2018 - meeting the sustainable development goals. Food and Agriculture Organization of the United Nations, Rome, Italy.

Farm Africa - Kenya Market-Led Aquaculture Program (2016). Strategic Environmental Assessment and Environmental Management Plan. Report No. 1655589-306435-1. Farm Africa Kenya Country Office: Nairobi, Kenya. 
Creative Commons User License: CC BY-NC-ND

Abstracted by: EBSCOhost, Electronic Journals Service (EJS), Google Scholar, Journal Seek, Scientific Commons,

Food and Agricultural Organization (FAO), CABI and Scopus

http://eoi.citefactor.org/10.11226/v25i4
Journal of Agricultural Extension

Vol. 25 (4) October, 2021

ISSN(e): 24086851; ISSN(Print); 1119944X

http://journal.aesonnigeria.org

http://www.ajol.info/index.php/jae

Email: editorinchief@aesonnigeria.org

Federal Ministry of Agriculture and Rural Development (FMARD) (2017) Fishery Statistics of Nigeria. Abuja, Department of Fisheries and Aquaculture, Federal Ministry of Agriculture and Rural Development.

Golden, C. D., Seto, K. L., Dey, M. M., Chen, O. L., Gephart, J. A., Myers, S. S., ... Allison, E. H. (2017). Does Aquaculture Support the Needs of Nutritionally Vulnerable Nations? Frontiers in Marine Science, 4. doi:10.3389/fmars.2017.00159

Greene, H. W. (2018). Econometric Analysis, $8^{\text {th }}$ Edition. Pearson Education, New Jersey.

Kumar, G., Engle, C., \& Tucker, C. (2018). Factors Driving Aquaculture Technology Adoption. Journal of the World Aquaculture Society, 49(3), 447476. doi:10.1111/jwas. 12514

National Population Census (2006). Retrieved from www.population.gov.ng

Obiero, K. O., Waidbacher, H., Nyawanda, B. O., Munguti, J. M., Manyala, J. O., \& Kaunda-Arara, B. (2019). Predicting uptake of aquaculture technologies among smallholder fish farmers in Kenya. Aquaculture International, 27, 1689-1707. doi:10.1007/s10499-019-00423-0

Pauly, D., \& Zeller, D. (2017). Comments on FAOs State of World Fisheries and Aquaculture (SOFIA 2016). Marine Policy, 77, 176181. doi:10.1016/j.marpol.2017.01.006

Piñeiro, V., Arias, J., Dürr, J., Elverdin, P., Ibáñez, A. M., Kinengyere, A., Opazo, C. M., Owoo, N., Page, R. J., Prager, S. D., and Torero, M. (2020). A scoping review on incentives for adoption of sustainable agricultural practices and their outcomes. Nature Sustainability, 3, 809-820. doi:10.1038/s41893-02000617-y

White, P. (2017). Aquaculture Pollution: An Overview of Issues with a Focus on China, Vietnam, and the Philippines. Prepared for the World Bank, Washington, DC. 